\title{
The Roles of Animals in Chinese Flood Myths
}

\author{
LIAN Zelei \\ Hangzhou College of Commerce, Zhejiang Gongshang University, China \\ Received: May 25, $2021 \quad$ Accepted: June 18, $2021 \quad$ Published: November 30, 2021
}

To cite this article: LIAN Zelei. (2021). The Roles of Animals in Chinese Flood Myths. Asia-Pacific Journal of Humanities and Social Sciences, 01:3, 008-019, DOI: 10.53789/j.1653-0465.2021.0103.002

To link to this article: https://doi.org/10.53789/ j.1653-0465.2021.0103.002

\begin{abstract}
This paper offers an original and systematic explanation of the roles animals played in the main Chinese flood myths. It investigates the significance of their roles as a signifying exponent of the flood myth repertoire as they were recorded from high antiquity to early imperial times in the hope of deepening our understanding of the interesting and peculiar roles animals played in culture, politics, and human-animal relationship on the one hand, and myth narratives on the other. They are classified into four main categories: animals as causes of the flood, animals as the embodiment of the flood, animals as obstacles, and animals as assistants. And it is argued that these roles reveal how humans perceive their relationship with the animals.
\end{abstract}

Keywords: animals; flood myths; human-animal relationship

Notes on the contributor: LIAN Zelei is a teaching assistant at Hangzhou College of Commerce, Zhejiang Gongshang University. His academic interest lies in Chinese pre-modern texts and their translation and reception in the west.

\section{Introduction}

Tales of the flood are one of the fascinating categories of stories found in almost all cultures in the world and might also be the most studied genre of stories in all world mythologies. They were popular in the earliest stage of human society, and their charm has proven to be amazingly everlasting to this day. Dundes (1988) in his book has had a comprehensive and insightful discussion of the flood myth as a worldwide phenomenon and has inspired research in both a global and local context.

However, serious scholarship on the Chinese flood myth emerged relatively late and was not even known to the general public in China before the introduction of the concept of western mythology in the late 19th and early 20th centuries. In this regard, the Gushibian (Critiques of Ancient History) school has been pioneering in recognizing the elements of mythology that was generally believed to be genuine ancient history, which has facilitated later scholars' research and discussions on Chinese flood myths. But generally speaking, scholars affiliated with this school were more occupied with identifying individual mythic figures in historical writings than discussing the significance of particular motifs such as the flood myth.

Amid the vestiges of classical Chinese myths, stories of controlling a great flood figure prominently. These tales of taming the flood have provided a rich ground for contemplation on human society. Most studies on the 
flood myth have focused on individual figures. Anne Birrell in her seminal article complains that the significance of Chinese flood myths is undervalued even by Sinologists. She even coins the term "benign neglect" for this phenomenon: "Although both these written or oral traditions have long been known to Chinese and Japanese scholars and to Western Sinologists, it is true to say that the phenomenon of 'benign neglect' is generally manifest in the study of Chinese flood myths" (Birrell 1997: 214). This paper proposes a new perspective, i.e., to examine the roles of animals in prominent myth narratives to reexamine the significance of the Chinese flood myth. Several important clarifications need to be discussed here first.

To begin with, this is not a scientific zoological or biological survey of animals. "Animals" in this paper are defined as creatures or spirits that possess conspicuous animal features. Most of them discussed here are mythical animals, which have supernatural powers or are associated with such, but are based on actual animals.

Second, it's worth pointing out that there is not a coherent and systematic version of the so-called "Chinese flood myth" but various versions of "flood myths" which share the records of or reference to a mythical event of a past universal inundation, creating mayhem until suppressed by order. These records, though all in the form of short fragments, constitute actually a quite large corpus of Chinese flood myths and are the origin of a lot of differences, deviances, and contradictions. However, it is not the aim of this paper to "explain away" these textual problems to trace back or reconstruct a tricky original version of the flood myth. Rather, these written records, whatever their difference, are read primarily as evidence of the attitudes of the people of that period. The criteria for the inclusion of flood myths are their prominence and relevance. As observed in Anne Birrell's "The Four Flood Myth Traditions of Classical China" and Mark Lewis' The Flood Myths of Early China, there are four main flood myths in classical China, discerned by their protagonists, namely Nü Gua, Gong Gong, Gun, and $\mathrm{Yu}$, which are “女嗗”, “共工”, “鯀” and “禹” respectively in Chinese. This paper is situated within the four main flood myths. Chinese flood myths have so far had important insights into the political transition and tension, social institutions, marriage, lineage and household, social hierarchy and division, and so forth. Lewis (2006) provides an interesting and insightful philosophical and political reading of Chinese flood myths tradition. However, pertinent to this paper, no effort has yet been made to systematically examine the roles animals played in these flood myths, although they are all over the place if paid close attention to.

This paper intends to draw attention to the roles of animals in Chinese flood myths and shed light on the significance of these roles. The first part is a short introduction. It reviews previous scholarship on Chinese flood myths, especially the different approaches. It also discusses the significance of looking at the Chinese flood myth repertoire from the specific perspective of the roles of animals in these narratives. The second part investigates separately the four main roles of animals as the causes and embodiment of the flood and as obstacles and assistants in the flood narrative. The last part is the brief conclusion, summarizing and reconfirming the main findings of this paper.

\section{Animals as Causes of the Flood}

Scholars have long noted that, unlike the flood myth variants recorded in cuneiform clay tablets or in the Hebrew Bible, Chinese flood myths have no obvious causes. It is not the divine punishment bestowed by a dissatisfied god for human's evil deeds like in the famous Bible narrative, nor is it because humans simply have been too noisy and annoying like in Gilgamesh. But among the remaining vestiges of Chinese mythology repertoire, there are indications that it is animals that are responsible for instigating the great inundation in the first place. 
First, the Shanhaijing 山海經 (The Book of Mountains and Seas), one of the most important primary sources and a treasure house of classical Chinese myths, has recorded eight strange animals which are associated with the emergence of the flood. These records all appear in the same syntax of "In the mountain $\mathrm{X}$, there is the beast Y. When Y is seen Z (the flood) will happen.” In Xishanjing 西山經 (The Book of Western Mountains), for example, it makes a note of a certain strange bird Manman 蠻蠻 from the mountain of Chongwu 崇吾 that is capable of bringing forth a flood:

崇吾之山……有鳥焉, 其狀如鳥, 而一翼一目, 相得乃飛, 名曰蠻蠻, 見則天下大水。（Yuan 1980：34）

My translation: In the mountain of Chongwu, there is a kind of bird whose figure is like a wild duck but has only one wing and one eye and has to be paired to fly. Its name is Manman. When it is seen, there will be a flood in the world. (The English translation is mine unless otherwise indicated)

The link between a certain animal and the flood, as recorded in the Shanhaijing can be summarized in the chart below.

\begin{tabular}{|c|c|c|c|}
\hline Mountain X & Beast $Y$ & Outcome $\mathbf{Z}$ & $\begin{array}{l}\text { Section of Occurrence } \\
\text { in the Shanhaijing }\end{array}$ \\
\hline Chongwu 崇吾 & Manman 蠻蠻 & $\begin{array}{l}\text { Flood in the world “見則天 } \\
\text { 下大水” }\end{array}$ & $\begin{array}{l}\text { Xishanjing《西山經》 } \\
\quad(\text { The Book of Western } \\
\text { Mountains) }\end{array}$ \\
\hline Changyou 長右 & Changyou 長右 & $\begin{array}{l}\text { Flood in the provinces and } \\
\text { counties “見則郡縣大水” }\end{array}$ & $\begin{array}{l}\text { Nanshanjing《南山經》( The Book of } \\
\text { Southern Mountains) }\end{array}$ \\
\hline Kongsang 空桑 & Lingling 軨軨 & $\begin{array}{l}\text { Flood in the world “見則天 } \\
\text { 下大水” }\end{array}$ & $\begin{array}{l}\text { Dongshanjing } \\
\text { 《東山經》 } \\
\text { ( The Book of Eastern Mountains) }\end{array}$ \\
\hline Shanshan 灲山 & Heyu 合宛 & $\begin{array}{l}\text { Flood in the world “見則天 } \\
\text { 下大水” }\end{array}$ & $\begin{array}{l}\text { Dongshanjing } \\
\text { 《東山經》 } \\
\text { ( The Book of Eastern Mountains) }\end{array}$ \\
\hline Ao'an 敖岸 & Fuzhu 夫諸 & $\begin{array}{l}\text { Flood in the area where it's } \\
\text { seen “見則其邑大水” }\end{array}$ & $\begin{array}{l}\text { Zhongshanjing } \\
\text { 《中山經》 } \\
\text { ( The Book of Middle Mountains) }\end{array}$ \\
\hline Guishan 却山 & Yuanyang 鹗尞 & $\begin{array}{l}\text { Flood in the area where it's } \\
\text { seen “見則其邑大水” }\end{array}$ & $\begin{array}{l}\text { Xishanjing } \\
\text { 《西山經》 } \\
\text { ( The Book of Western Mountains) }\end{array}$ \\
\hline Yushan 玉山 & Shengyu 勝遇 & $\begin{array}{l}\text { Flood in the kingdom when } \\
\text { it's seen “見則其國大水” }\end{array}$ & $\begin{array}{l}\text { Xishanjing } \\
\text { 《西山經》 } \\
\text { ( The Book of Western Mountains) }\end{array}$ \\
\hline Yangshan 陽山 & Chihu 叱呼 & $\begin{array}{l}\text { Flood in the area where it's } \\
\text { seen “見則其邑大水” }\end{array}$ & $\begin{array}{l}\text { Zhongshanjing } \\
\text { 《中山經》 } \\
\text { ( The Book of Middle Mountains) }\end{array}$ \\
\hline
\end{tabular}

Table 1: A table on the textual link between the appearance of a certain animal and the flood

Although there's no way of determining whether the flood mentioned in these records is the flood in the universal flood myth, we can, however, be certain that the compilers of this "myth book" no doubt associate the flood with certain animals appearing in the human world or simply to be seen by human beings. Among the eight notes listed above, the beasts residing in the mountains Changyou 長右, Ao’ an 敖岸, Guishan 邽山, Yangshan 陽山 unmistakably have the power of wreaking havoc in human territory, indicated by the place references Jun 
xian 郡縣 (provinces and counties), Yi 邑(areas or states) and Guo 國(kingdoms or states). The rest three records refer to the place Tianxia 天下 (world), which literally translates as "under the sky". Although the term is very likely used here as a synonym for kingdom or state and also refers to the human habitat, it is hard to ascertain due to the lack of context.

The significance of these records lies not only in stating that animals have the power of bringing forth floods but more importantly also in making the innuendoes that the disaster represented by the flood in a mythological sense is a conflict between beasts and humans, as surmised by the compilers of the Shanhaijing of what had happened in the high antiquity. These references are perspicuous in bearing witness to the beasts intruding into the human realm, substantiating the role of animals as the causes of the flood, hence the disorder it brings and represents. It is also worth noting that in the whole Shanhaijing, the encyclopedia of strange lands, people, plants, and stones, animals only are endowed with such impressive power of authoring the flood.

In addition to these strange animals only related to the flood in the Shanhaijing, there are also strong indications in the main flood myth repertoire that Gong Gong, one of the central flood figures, is also identified as the originator of the flood as an aquatic creature. Though only vestiges of the original scenario are left to us in texts, extant records would suffice to corroborate the theory that Gong Gong caused complete mayhem in the world by creating the great flood.

In the Huainanzi 淮南子, another important source for Chinese myths and generally believed to be compiled in the early Han dynasty, there are at least two places that depict Gong Gong as the creator of the flood: "In the time of Shun, Gong Gong stirred up the waters into a rampant flood that ran against the Hollow Mulberry" (Lewis 2006: 57). And in a different section, "Gong Gong caused the watery disaster, as a result, Zhuanxu killed him" (Chen 2012: 673).

Although no explicit accounts are given as to how Gong Gong caused the flood exactly, according to other accounts related to the mythic figure Gong Gong, it is highly likely that he did it by butting the mythic $\mathrm{Mt}$. Bu Zhou, a pillar connecting the heaven and earth. Also in the Huainanzi, there is a similar account:

昔者共工與顓頊爭為帝, 怒而觸不周之山。天柱折, 地維絕。天傾西北, 故日月星辰移焉; 地不滿東南, 故水潦塵埃歸焉。(Chen 2012: 522)

My translation: Long ago, Gong Gong battled with Zhuan Xu to become Thearch. In his anger, he butted against Mt. Buzhou. Heaven's pillar broke and Earth's cord snapped. Heaven tilted toward the northwest, so the sun, moon, stars, and planets moved in that direction. Earth was left unfilled in the southeast, so the watery floods and the silted soil tend in that direction.

When dealing with the story of the great flood, other major classical texts are coherent in mentioning the very unnatural act of "water flows backward". For example, the Book of Mencius tells us that "In the time of Yao, the water flowed backward and flooded the middle kingdom" (Yang 2010: 128). The specific phrase "water flows backward" also appears in another passage in Mencius:

昔上古龍門未開, 吕梁未發, 河出孟門, 大溢逆流……名曰鴻水。水逆行, 謂之浲水。(Yang 2010: 301)

My translation: A long time ago, the Dragon Gate was not opened, the Lü Range was not yet passed, and the Yellow River [flowed] over the Meng Gate. Great deluge flows backward... Its name is flooded. When water flows backward, it is called a flood.

When pieced together with the story of Gong Gong butting the Mt. Bu Zhou as mentioned above, it is clear that "water flows backward" should be the result of this act and further corroborates that he is the cause of the flood. We can see from these three excerpts that "water flowing backward" is a highly unnatural act of nature that 
embeds the idea of a state of chaos, although no further explanation is given as to why the chaos came into being in the first place.

If the link between Gong Gong and the cause of the flood can be soundly established, then what is Gong Gong to be exact? William G. Boltz proposes in his seminal article "Kung Kung and the Flood" that phonetically Gong Gong has the same roots as snakes or dragons: “The two-character phrase she lung 蛇龍 'snakes and dragons' that we noted in the second Mencius passage I would like to suggest is in origin a dimidiation and semanticization of the same root of Kung Kung, meaning 'wanton/ disorder"” (Boltz 1981: 151).

Textual evidence abounds in identifying Gong Gong as an aquatic creature. Several sources recognize him as a hybrid of human and snake (or dragon). Lushi 《路史》( History of the Way) mentions that "Gong Gong has a human face, a snake body, and red hair”(Luo 1936: 692). Zuo Zhuan《左傳》(Zuo's Commentary) points out that "Gong Gong has a son called Gou Long" (Yang 2009: 276). The first record indicates that Gong Gong is a mythical hybrid spirit, with a human face but in the form of a snake (or dragon). It's no wild conjecture that the image of Gong Gong comes ultimately from the image of a water creature like a snake. It might be the projection of the idea that people would once believe such mythical beasts could be capable of creating watery mayhem. And in the last instance, Gong Gong's attributed son has the name long 龍 in it, indicating a close relationship with these two.

\section{Animals as Embodiment of the Flood}

When it comes to the main flood myth narratives, the role of animals as the embodiment of the flood itself becomes more eminent, especially in the narratives surrounding the mythical figure Gong Gong and Gun 鯀.

Illuminating in the case of identifying Gong Gong as an embodiment of the flood can be found in Yaodian 《堯典》(The Book of Yao). There the Sovereign Lord Yao asks his advisor Huandou 驩㿟 to recommend someone capable of running the state. This certain Huandou proposes Gong Gong, but the advice is turned down as Yao believes that Gong Gong is reverent only in appearance but is in fact subversive.

帝曰: 吁! 靜言庸違, 象恭滔天。帝曰: 咨! 四岳, 湯湯洪水方割, 蕩蕩懷山襄陵, 浩浩滔天。( Qu 2011: 42)

Lewis' translation: Ah, quiet in words, but his acts are contrary. He seems respectful but floods rampant to Heaven. Thearch [Yao] said, "Alas, Four peaks, swishing and swirling, and the great flood now destroys. Surging and shaking, it enfolds mountains and surmounts hills. Rushing and limitless, it floods rampant to Heaven". (Lewis 2006: 64)

As William Boltz (1981: 142) famously observed, the specific phrase in this passage, "run rampant to Heaven", as clearly a negative description, applies not only to Gong Gong but also to the flood itself. The repetition of the same phrase within the same passage and context basically rules out the possibility of textual coincidence. So this short passage is revealing in identifying that Gong Gong is, in fact, the symbol and embodiment of the flood itself.

Besides this phrase "run rampant to Heaven", the character yin 淫 (excess), which also appears many times in flood myth narrative, also discloses that both Gong Gong and Gun are closely related to the flood. In most discourses on flood myths, the word yin is applied to the description of the character of Gong Gong and Gun, used to criticize their personal deficit and their way of dealing with the flood. Take the passage from Guoyu 《國語》 (The Discourses on States) as an example: 
昔共工棄此道也, 虞于湛樂, 淫失其身, 欲雍防百川, 墮高堙庳, 以害天下。皇天弗福, 庶民弗助, 禍亂并 興,共工用滅...有崇伯鯀,播其淫心, 稱遂共工之過,堯用歿之于羽山。(Chen 2013：402)

Lewis' translation: But long ago, Gong Gong renounced this Way. Taking pleasure in self-indulgent and losing himself in excess, he desired to block up all the rivers, lower the high ground to fill in the low places, and thereby ruin the world. August Heaven did not bless him, the common people did not help him, calamities arose on all sides, and so Gong Gong was destroyed... Gun, lord of Chong, spread his idea of excess, so he repeated the error of Gong Gong. And Yao had him killed in the mountain of Yu. ( Lewis 2006: 56)

In almost all the versions of the Gong Gong flood narratives, he is depicted as a malefactor who is associated with chaos and needs to be taken care of. It is clear from the negative description of Gong Gong that the character yin means excess and self-indulgence and closely resembles the description of the flood itself. Birrell (1997: 234) rendered the character yin as "sexual excess" and "sexual libido", but judging from the context of the occurrences of this character in the narrative, it has nothing to do with sex but only indicates a state of excess. So just like the phrase "run rampant to Heaven", it is another elucidating indication that the malefactor in the flood myth symbolizes the flood itself.

The same analysis also goes to Gun, who is phonetically related to Gong Gong and much alike Gong Gong is another famous malefactor in classical Chinese flood myths. Both are rebellious, most famously represented by Gong Gong defying the sovereign god and Gun stealing the Xirang 息壤 ( self-growing earth) from the sovereign god without consent. Both have conspicuous animal (aquatic to be exact) features and perform physical transformations into animals. And both are portrayed as the chaos bringer or failure. In fact, the striking similarity between these two figures has long led scholars to suspect that they might be the same character in the primordial flood myth. It is clearly no mere speculation that both can be credited to be the embodiment of the flood.

\section{Animals as Obstacles}

The third interesting role of animals discerned in flood myths is as the obstacles in the course of heroic figures taming the flood. The best examples are found in the myths of Yu the Great. In plenty of myths surrounding $\mathrm{Yu}$, he is celebrated above all for having successfully contained the flood and ended the sufferings of humans. Yu is challenged to clear the dreadful obstacles represented by the defiant dragons and snakes in this strenuous process. The best example can be found in the Mencius passage:

當堯之時, 水逆行, 汇濫於中國。蛇龍居之, 民無所定。下者為巢, 上者為營窟。書曰: 洚水警余。浲水 者, 洪水也。使禹治之, 禹掘地而注之海, 驅蛇龍而放之菹。水由地中行, 江、淮、河、漢是也。險阻既遠, 鳥獸 之害人者消, 然後人得平土而居之。( Yang 2010：158)

Lewis' translation: In the time of Yao, the waters reversed their course and overflowed the middle kingdoms so that snakes and dragons dwelt there. The people had no fixed dwellings, so those in lower regions made nests in trees, while those in higher ones lived in mountain caves. The Documents' saying, "The floods are a warning to me", refers to this inundation. [Yao] had Yu put it in order. Yu dredged out the land and channeled the rivers to the sea. He expelled the snakes and dragons to the grassy swamps. The movement of the water outward from the land formed the Jiang, Huai, Han, and Yellow Rivers. As the dangers were removed to the distant regions, the harm of the snakes and dragons vanished. Only then were people able to obtain level land to dwell on. (Lewis 2006: 33) 
In this famous account, the clash between beasts and humans is imminent. The flood brings a collapse of the distinction between these separate groups, and beasts like snakes and dragons intrude into the human domain and take up habitat. Yu was trying to reintroduce the distinction between humans and animals and rebuild the human territory and civilization. And naturally, in this undertaking Yu has to "expel[led] the snakes and dragons to the grassy swamps" until "the dangers were removed to the distant regions, the harm of the snakes and dragons vanished".

The Huainanzi and Lüshi Chunqiu «呂氏春秋» (Annals of Master Lü) are consistent in pinning down the sabotage by a yellow dragon, only to be scared away by the determined and undaunted Yu:

禹南省方, 濟于江, 黃龍負舟, 舟中之人五色無主, 禹乃熙笑而稱曰: 我受命於天, 竭力而勞萬民。生寄 也,死歸也,何足以滑和? 視龍猶蝘蜓,顏色不變,龍乃弭耳掉尾而逃。(Chen 2012: 366)

My translation: Yu toured the southern provinces. When crossing the Yangtze River, a yellow dragon clutched the boat. Passengers in the boat lost control of their five senses. Yu laughed and said, "I am sent by Heaven and devote myself to laboring for all my people. To live is to sojourn. To die is to go back ( where I came from). Why should I be worried? " [ Yu] regarded the dragon like a gecko and didn' $t$ change his facial expression. Then the dragon hung down its ears, lowered its tail, and ran away.

禹南省, 方濟乎江, 黃龍負舟。舟中之人, 五色無主。禹仰視天而歎曰: 吾受命於天, 竭力以飬人。生, 性 也; 死,命也。余何憂於龍焉? 龍俛耳低尾而逝。( Ji 2014: 102)

My translation: Yu toured southern provinces. When crossing the Yangtze River, a yellow dragon clutched the boat. Passengers in the boat lost control of their five senses. Yu looked up at the sky and sighed, "I am sent by Heaven and devote myself to saving people. To live is nature. To die is destiny. Why should I be worried about the dragon?" Then the dragon hung down its ears, lowered its tail, and ran away.

These two accounts have vividly portrayed a righteous and courageous $\mathrm{Yu}$, whose moral integrity, expressed through his speech, makes the yellow dragon ashamed and escape willingly out of shame and fear ("hung down its ears, lowered its tail”). But in the extraordinary time of great flood and catastrophic sufferings, Yu also deploys extraordinary methods, i.e. the merciless execution, to ensure his engineering project runs smoothly. The local gazette of Wushan 巫山 contains an entry on how Yu's meticulousness and intolerance towards mistakes earned the name of a local place:

\section{斬龍臺, 治西南八十里。……相傳禹王導水至此,一龍錯行水道,遂斬之。( Yuan 1985: 367)}

My translation: The Zhan long tai (dragon slaughtering platform) lies 80 li southwest of the district... Legend has it that when King $\mathrm{Yu}$ was controlling the flood and passed this place, a dragon went on the wrong channel. So it was executed.

This record also hints at the large scale of Yu's animal construction team, which must have contained at least lots of dragons, led probably by the famous Responding Dragon. Besides the minor legend of Zhan long tai, the most famed animal obstacle in the way of $\mathrm{Yu}$ controlling the flood is probably the snake figure malefactor Xiangliu. See, for example, the record in the Shanhaijing:

共工之臣曰相柳氏, 九首, 以食于九山。相柳之所抵, 厥為澤谿。禹殺相柳, 其血腥, 不可以樹五穀種。 禹厥之, 三仞三沮, 乃以為眾帝之臺。在芘崙之北, 柔利之東。相柳者, 九首人面, 蛇身而青。( Yuan 1980: 198)

Lewis' translation: Gong Gong's servant was named Xiangliu. He had nine heads to eat at all Nine Mountains. Whatever Xiangliu touched became marshes and valleys. Yu killed Xiangliu, but his blood was 
putrefied, so no seeds could be planted [in land touched by the blood]. Yu dug it out to a depth of 3 rens [about 4.8 meters], flushed it out three times, and then took it [ the dug up soil] and made the towers of all the thearchs which lay to the north of Kunlun....Xiangliu had nine heads with human faces and the body of a blue-green snake. (Lewis 2006: 77)

Although no direct textual evidence pinpoints Yu's executing of Xiangliu to the flood, the links are, however, well established. First, as the Mencius passage indicates, the animal obstacles in the flood myth are represented by the "snakes and dragons". And Xiangliu in the Shanhaijing is certainly a snake figure, with "nine heads with human faces, and the body of a blue-green snake". Second, Xiangliu is the servant or minister (chen 臣) of the famous flood malefactor Gong Gong, and Gong Gong connects with the flood narrative. Moreover, textually the description that "whatever Xiangliu touched became marshes and valleys" suggests his ability to use or take advantage of the flood to consume dry land and thus human territory and drag the world into a watery mess. So naturally, he is the archenemy and obstacle of Yu since his project is mainly to fill up these lowlands. Yu's killing Xiangliu is the decrypted clash between the two ideals of order and chaos. So not surprisingly, in his laborious journey to contain the flood, the triumph of Yu necessitates the execution of Xiangliu.

Not directly related to the Yu myth but run almost parallel in motif and basic plot of killing dragons to tame the water is the myth of the fathers and son Li Bing and Er Lang. Li Bing is a historical figure famous for his water diverting engineering work of Dujiangyan 都江堰. The myths surrounding Li Bing and his son are likely to have been inspired by the myth of $\mathrm{Yu}$, the flood tamer and has become a local variant of the Yu myth over time. Worth noting in this regard is a passage on their great deeds:

夫有非常之患, 必生非常之人, 彼蒼仁愛斯民, 往往而然, 亦非獨李公父子也。公釃二渠, 斬潛蛟, 約水 神, 痤石犀……能與大禹治神奸、驅蛇龍先後一轍。……郎奉父命而斬蛟……(Yuan 1980: 171)

My translation: In a time of extraordinary hardship, there will be extraordinary people. The merciful Heaven loves humans. This is often the case and not only [shown] in Li [Bing] and his son. He and his son dived [ into the river] to fight the Jiao dragon, went face to face with the River God, buried the stone bull .... In dealing with gods and evil spirits and driving away snakes and dragons, [their deeds] follow the trace of $\mathrm{Yu}$ the Great... Er Lang carried out the order of his father and killed the Jiao dragon.

Though comparatively late in time, the text itself has compared Li Bing and Er Lang to Yu the great flood tamer ("follow the trace of Yu the Great"), in which we again see reference to the driving away of "snakes and dragons", which is a unique symbol of Yu taming the flood. The killing of the Jiao 蛟 dragon is more eminently the story variant of Yu killing Xiangliu. According to this account and a lot of others, either Li Bing or his son Er Lang found the evil dragon, the cause of the local flood, and successfully killed it during fighting in the river. The myth of their heroic deeds shares with that of Yu in sorting out the obstacles represented by animals, especially the dragon and snake. This again indicates the ultimate distinction that underlay early Chinese thought on morality was the separation of men from beasts. Being the obstacles is their inevitable role and the necessary plot to underline this message.

The materials quoted above demonstrate that animals, especially snakes and dragons can pose as knotty obstacles in the myths of heroes taming the flood. To respond, as these materials also show, heroes in these myths deploy a wide range of options to tackle the problem. They can either turn to their moral integrity to make animals ashamed and escape, like in the case of $\mathrm{Yu}$ and the yellow dragon. But this method is, of course, not the panacea. The hero would sometimes have to resort to violence. As the Mencius passage shows, the main method the hero uses is to reintroduce the separation of humans and beasts by driving animals away to the edges of the 
world, where they no longer pose threats to humans. But in extreme cases, the hero would have to execute the animals in question, either for the establishment of authority like the killing of a wrongdoing dragon or to defeat and destroy them completely, like in the case of Yu's act of executing Xiangliu.

\section{Animals as Assistants}

Contrary to the roles of animals as causes and embodiment of the flood and the obstacles, in the main flood myth repertoire, animals also take up a very different role as assistants to help protagonists quell the flood. In flood myth narratives surrounding Gun and $\mathrm{Yu}$, we find the owl, turtle, dragon, fish, snake, dog and pig have contributed to the taming of the flood as assistants to Gun and Yu in their own way.

Tienwen 天問 (Questions of Heaven) has preserved the earliest reference to the myth of Gun controlling the flood. In it we find a laconic and obscure line describing how a bird a turtle influenced Gun: "When the owl carried [it] in its beak, and the giant turtle dragged its tail, why did Kun obey them?" (Lin 2009: 146)

The role of animals as assistants is more manifest in the abundant flood myth narratives surrounding Yu, who is no doubt the most famous heroic figure in taming the great flood and is also the most studied figure. Gu Jiegang 顧頡剛 (1893-1980) and other colleagues (most famously Yang Kuan 楊寬 (1914-2005), Tong Shuye 童書業 (1908-1968) in the school of Gushibian have been pioneers in revealing the mythic nature of the famous $\mathrm{Yu}$ and pointed out that the earliest textual evidence on Yu was found in the Shijing 詩經 (The Book of Songs). Before the discussion on various animals aiding the great flood tamer, it is worth noting that Yu himself is very much a mythic animal. Though not supported by straightforward evidence, Yu is firstly phonetically and lexically related to fish or dragon. Also, like Gun, he was able to transform into a bear or the Nai dragon. Moreover, his peculiar "gait of Yu" 禹步 also suggests a firm link with aquatic animals like fish. The plenty of hints might help explain Yu's relationship with animals when taming the flood.

In the course of $\mathrm{Yu}$ channeling the great flood, there is a lot of textual evidence on how he was aided by dragons, turtles, fish snakes, dogs, and even a pig. The most prominent animals assistants are the dragons, especially the Yinglong 應龍 (Responding Dragon). In the Questions of Heaven there is one question pondering on the role of the responding dragon in helping Yu tame the flood: "The Responding Dragon in the rivers and seas, how did it channel and where did it pass through?" (Lin 2009: 63) Although the verse is too laconic to help us understand the whole story, we do know that the Responding Dragon is related to water (represented here by "rivers and seas") and it is helping Yu control the flood by its acts of "channel" and "pass-through". In one annotated version of the Shanhaijing, there is a further description as to how exactly the Responding Dragon helped Yu:

禹治水,有應龍以尾畫地, 即水泉流通。禹因而治之。(Yuan 1980: 310)

My translation: When Yu was controlling the flood, Ying long ( responding dragon) touched the ground with its tail. The water and springs were immediately channeled. Yu then was able to control the flood.

Seen together with the verse in the Questions of Heaven, we now know that Yinglong would use its tail to open new channels on the ground to dredge the flood. In other texts, it is another kind of dragon, the yellow dragon, who is using its tail to dredge the water. Or in some texts, it simply mentions some certain "divine dragon" 神龍. The use of the adjective Shen 神 (divine) is revealing in adding to the narrative that Yu's work is blessed by heaven and the dragons were sent down to aid him to finish the great channeling project.

禹盡力溝洫, 導川夷岳, 黃龍曳尾于前, 玄龜負青泥于后。玄龜, 河精之使者也。龜領下有印, 文皆古䇡 
字作九州山川之字。禹所穿警之處, 皆以青泥封記其所, 使玄龜印其上。(Yuan 1985：155)

My translation: Yu devoted all his strength to the water channels, guiding the rivers and leveling the peaks. A yellow dragon dragged its tail in front of him [ to carve out channels] and a black turtle carried along with blue-green mud behind. This black turtle was the emissary of the spirit of the Yellow River. Beneath the turtle's chin, there was a seal whose characters were all in the old seal form. These formed the graphs for [the names of] all the mountains and rivers of the Nine Provinces. Wherever Yu had dug out a channel, he used the blue-green mud to seal up and record the place, then had the black turtle press down the seal on top of it.

The first text in Shiyiji 拾遺記 (Notes on Collecting the Forgotten Past) also records a black turtle who is the emissary of the Yellow River spirit. His role is twofold. First, he carries the blue-green mud on its back, but he also applies the blue-green mud on the ground to make marks using its chin.

As for fish (human-fish hybrid to be exact), in the flood myth, it is the image of the Yellow River spirit who bestows on Yu the River Chart, probably a map guiding Yu's course:

禹理洪水,觀于河, 見白面長人魚身出, 曰 : “吾河精也。”授禹河圖而還于淵中。(Zhu 2006: 51)

My translation: When Yu was dealing with the flood, he looked by the Yellow River and saw a creature with a white face and a long body like a fish coming out of the river. It said, "I am the river spirit". It presented $\mathrm{Yu}$ with the river chart and returned to the abyss.

昔夏禹觀河, 見長人魚身出, 曰: “吾河精”,蓋河伯也。(Yuan 1985：164)

My translation: A long time ago, Yu of Xia looked by the Yellow River and saw a creature with a long body like a fish coming out of the river. It said, "I am the river spirit". It must be the Lord of the Yellow River.

In the chapter on $\mathrm{Yu}$ in the Shiyiji, we see the pig, dog and the snake also helped Yu:

禹鏊龍門, 至一空岩, 幽暗不可復行。禹乃負火而進。有獸狀如豕, 銜夜明之珠, 其光如燭。又有青犬, 行吠于前……万探玉簡授禹, 使度量天地。禹即執此簡, 以平定水土。蛇身之神, 即羲皇也。(Wang 1981: 68)

My translation: Just like the Yellow River spirit presenting the River Chart to $\mathrm{Yu}$, here in this account, a snake figure believed to be Fu Xi presented Yu with a jade chart, possibly the same as the River Chart. The pig and dog in the cave also presented Yu with the magical pearl, though no specifics are given on how this pearl is to be used.

We find from these accounts translated and discussed above that $\mathrm{Yu}$ has far more animal assistants than Gun, which indicates Yu's unmistakable status as the main hero in taming the flood. In these stories, dragons help Yu carve out channels by its tail. Yellow River spirit, the fish, as well as Fu Xi the snake gave Yu the magical chart to measure to the world. The turtle carried for Yu the mythical mud to mark and divide the land, to reintroduce order after the chaos brought by the flood. The pig and dog also offered presents to Yu.

After the exhaustive analysis of the role of animals as assistants, the important question remains: why would these mythical animals appear to provide aid to tame the flood? Isn' $t$ it an obvious contradiction with previous roles discussed above as causes, the embodiment of the flood, and as obstacles standing in the way of protagonists controlling the flood?

An ostensible explanation is that these elements would make sensible stories. The hero must have required some help. Given that Gun and Yu have obvious animal attributes, it is convincing to add to the story the element that they have received help from fellow mythic beasts. But more importantly, the diversified roles of animals in 
Chinese flood myth narratives reflect the dynamic and changing idea of the human-animal relationship, projected by the myth makers, later storytellers, and common listeners across generations and buried deep in their cultural consciousness and memories. In this regard, animals are good to think with. First, humans are afraid of animals and regard them as a great threat. Some animals intrude into human territory. They are capable of menacing agriculture, devouring human livestock, their domesticated animals, and even attacking humans. They are fearsome, merciless, sly, powerful, and most depressingly the danger they pose for humans seems always imminent. Then we are not surprised as humans project their fear of animals into the flood narrative and make animals the cause, the embodiment of the flood, and the obstacles in taming the flood. But in the meantime, living side by side with animals has also taught humans to appreciate the value of animals and learn to utilize their help. The domestication of animals is the epitome of the positive side of the human-animal relationship. Then again we won' $t$ be amazed that animals can also be assistants in the flood stories. In short, the different roles of animals in these fascinating narratives respond to how humans perceive their relationship with the animals.

\section{Conclusion}

This paper has delineated and examined the four main roles of animals in the Chinese flood myth repertoire, i.e. as the cause and embodiment of the flood, and as the obstacles and assistants. However, the division and examination of these four main roles of animals are in no way indicate that these roles are compartmented and should be interpreted in isolation. On the contrary, only by being taken and seen together can they yield much richer findings for us to better understand the nature of animals in these myths.

These four different roles can easily overlap with each other. Concerning the flood, we see how animals can be both the cause and the embodiment of the flood. As the analysis shows, Gong Gong in some accounts can both be the cause of the flood and the personification of the flood itself. They both rely on the animals' close relationship with the flood since the threat posed by animals crossing into the human realm makes it the best candidate the metaphor for the flood, a symbol of the collapse of the distinction of humans and animals. The role of animals as obstacles is a logical extension of these previous two roles as causes and the embodiment of the flood because when they introduce and represent a state of chaos, they naturally take up the role of rebels and enemies for anyone who would try to end the flood and re-establish order to the world.

The important question remains that why would these mythical animals appear to provide aid to tame the flood? Isn't this an obvious contradiction with previous roles discussed above as causes, the embodiment of the flood, and as obstacles standing in the way of protagonists controlling the flood?

An ostensible explanation is that these elements would make sensible stories. The hero must have required some help. Given that Gun and Yu have obvious animal attributes, it is convincing to add to the story the element that they have received help from fellow mythic beasts. But more importantly, the diversified roles of animals in Chinese flood myth narratives reflect the dynamic and changing idea of the human-animal relationship, projected

by the myth makers, later storytellers, and common listeners across generations and buried deep in their cultural consciousness and memories.

In this regard, animals are good to think with. First, humans are afraid of animals and regard them as a great threat. Some animals intrude into human territory. They are capable of menacing agriculture, devouring human livestock, domesticating animals, and even attacking humans. They are fearsome, merciless, sly, powerful, and most depressingly, the danger they pose for humans seems always imminent. Then we are not surprised 
as humans project their fear of animals into the flood narrative and make animals the cause, the embodiment of the flood, and the obstacles in taming the flood. But in the meantime, living side by side with animals has also taught humans to appreciate the value of animals and learn to utilize their help. The domestication of animals is the epitome of the positive side of the human-animal relationship. Then again, we won't be amazed that animals can also be assistants in the flood stories. In short, the different roles of animals in these fascinating narratives respond to how humans perceive their relationship with the animals.

The role of animals as the embodiment of the flood is the theme of animals crossing into the human realm, which is a frequent feature of flood lore in China. These mythical beasts bring chaos, fear, and collapse of the distinction between animals and humans, epitomized by the image of Gong Gong and Gun, and it has to be killed off or defeated, symbolizing the ultimate triumph of order over chaos.

This theme of hybridization, the joining of men and animals in a common enterprise, reflects the issue of the disappearance of boundaries that was central to the flood myth in China as in other parts of the world and marks that the absence of boundaries as an essential precondition to the structuring of the world.

\section{References}

Allan, S. (1991). The shape of the turtle: Myth, art, and cosmos in early China. Albany: State University of New York Press.

Birrell, A. (1993). Chinese mythology: An introduction. Baltimore: The Johns Hopkins Press.

Birrell, A. (1994). Studies on Chinese myth since 1970: An appraisal. History of Religions, 33, 380-393.

Birrell, A. (1994). Studies on Chinese myth since 1970: An appraisal. History of Religions, 34, 70-94.

Birrell, A. (1997). The four flood myth traditions of classical China. T' oung Pao, 83, 213-259.

Boltz, W. G. (1981). Kung kung and the flood: Reverse euhemerism in the 'Yao tien' . T' oung Pao, 67, 141-153.

CHEN Guangzhong. (2012) . trans. The book of master Huainan. Beijing: Zhonghua Book Company.

CHEN Jianxian. (2013). On the turtle and stone lion in Northern China flood myth. The Central Plain Culture Research, 1, $108-112$. CHEN Tongsheng. (2013) . trans. The discourses on states. Beijing: Zhonghua Book Company.

Dundes, A. (1988). ed. The flood myth. Berkeley: University of California Press.

JI, Danyang. (2014) . Lüshi chunqiu with Translation and Annotations. Shanghai: Shanghai Sanlian Bookstore.

Lewis, M. E. (2006). The flood myths of early China. Albany: State University of New York Press.

LIN Jiali. (2009) . trans. Songs of Chu. Beijing: Zhonghua Book Company.

LUO Mi. (1936) . History of the way. Shanghai: Zhonghua Book Company.

McNeal, R. (2012). Constructing myth in modern China. The Journal of Asian Studies, 71, 679-704.

Pankenier, D. W. (2013). Astrology and cosmology in early China: Conforming Earth to Heaven. Cambridge: Cambridge University Press.

QU Wanli. (2011). Shangshu with modern annotations and translation. Beijing: New World Press.

Sterckx, R. (2002). The animal and the daemon in early China. Albany: State University of New York Press.

WANG Jia. (1981) . Notes on collecting the forgotten past. Beijing: Zhonghua Book Company.

YANG Bojun. (2010). Mencius with translation and annotations. Beijing: Zhonghua Book Company.

YANG Bojun. (2009). Zuo's commentary on Chunqiu with annotations. Beijing: Zhonghua Book Company.

YUAN Ke. (1980). Shanhaijing with annotations. Shanghai: Shanghai Classics Publishing House.

YUAN Ke. (2012). Chinese myths and legends. Beijing: World Publishing Corporation.

YUAN Ke \& ZHOU Ming. (1985). comp. Collection of materials on Chinese myths. Chengdu: Sichuan Academy of Social Sciences Press.

YANG Kuan. (1982) . Gushibian. Shanghai: Shanghai Classics Publishing House.

ZHU Hailei. (2006) . Annotated translation of Shizi. Shanghai Classics Publishing House. 